\title{
SOME NEW SOBRALIAE FROM COSTA RICA AND PANAMA
}

\author{
Robert L. DressleR' \& Diego Bogarín \\ Jardín Botánico Lankester, Universidad de Costa Rica, P. O. Box 302-7050 Cartago, Costa Rica. \\ Centro de Investigación en Orquídeas de los Andes “Ángel Andreetta”, \\ Universidad Alfredo Pérez Guerrero, Ecuador. \\ ${ }^{1}$ Corresponding author: kerry@bio-photo.com
}

\begin{abstract}
A new species of Elleanthus: E. carinatus and three new species of Sobralia: S. fragilis, S. geminata from Costa Rica and S. sotoana from Panama are described and illustrated.

Resumen: Una nueva especie de Elleanthus: E. carinatus y tres nuevas especies de Sobralia: S. fragilis, S. geminata de Costa Rica y S. sotoana de Panama se describen y se ilustran.
\end{abstract}

Key words/Palabras Clave: Sobraliae, Elleanthus carinatus, Sobralia fragilis, Sobralia geminata, Sobralia sotoana, new species, Costa Rica, Panama.

Here we describe several new species that have been found in the last few years. All are cultivated in the Lankester Botanical Garden, have flowered here, and material has been pressed from the cultivated plants.

\section{Elleanthus carinatus Dressler \& Bogarín, sp. nov.}

TYPE: Costa Rica. Cartago: límite entre Turrialba y Jiménez, La Suiza, Pejivalle, Fila Rincón de la Esperanza, entre Río Atirro y Río Nubes, 946’43.3”N 83³7’36.0”'W, $1150 \mathrm{~m}$, bosque muy húmedo premontano, pressed from cult. 10 Aug. 2009, R.L. Dressler 7069 (holotype: CR; isotype: JBL-spirit). FIG. 1, 8A.

Elleantho cynarocephalo (Rchb.f.) Rchb.f. affinis, bracteis brunneo-incarnatis pallentibus, petalis oblanceolatis, floribus e basi inflorescentiis primis aperientibus differt.

Roots to $8 \mathrm{~mm}$ in diameter. Stems to $90 \mathrm{~cm}$ (doubtless becoming taller); sheaths slightly scurfy. Leaves $22-30 \times 4-5 \mathrm{~cm}$, petiole ca. $5 \mathrm{~mm}$, blades elliptic-lanceolate, acuminate, with 7 prominent veins beneath. Inflorescence capitate, ca. $4.5 \times 4.0 \mathrm{~cm}$; lower bracts green, upper bracts pale brownish pink. Flowers rose-purple, inflorescence bracts oblong, acute, ca. 2.5 x 7.0-8.0 mm, with prominent median keel distally, this ending in apicule or mucro. Dorsal sepal $11 \mathrm{x}$
$3 \mathrm{~mm}$, elliptic, acute. Lateral sepals $12.0 \times 4.5 \mathrm{~mm}$, symmetrical. Petals $10.5 \times 3.0 \mathrm{~mm}$, oblanceolate. Lip 14-15 × $15 \mathrm{~mm}$, blade flabellate, emarginate, margins serrulate. Pollinia 8 , obovate.

The genus Elleanthus is clearly a relative of Sobralia. In the field, larger plants with unbranched stems may be difficult to assign to either genus with confidence unless there are at least remains of an inflorescence.

Garay (1978) recognizes several sections within Elleanthus, and treats the members of Section Cephalelyna, mostly large or very large plants with capitate inflorescences and a prominent "mentum" beneath the column. For many years, most members of this group were called Elleanthus capitatus. Garay (1978) offers a key to the sections of Elleanthus, and treats ten distinct species in Section Cephalelyna. Now E. capitatus, sensu stricto, is a Peruvian species, while the E. "capitatus" of Mexico and Central America is E. cynarocephalus.

Most, if not all, of the species of this section commonly produce a clear, mucilaginous material on the inflorescence that may serve to protect the flowers and developing buds from insect damage. Neither of the Costa Rican plants that we discuss here produced appreciable mucilage, but flower parts of the new species here described definitely exuded some mucilage when preserved in FAA. 

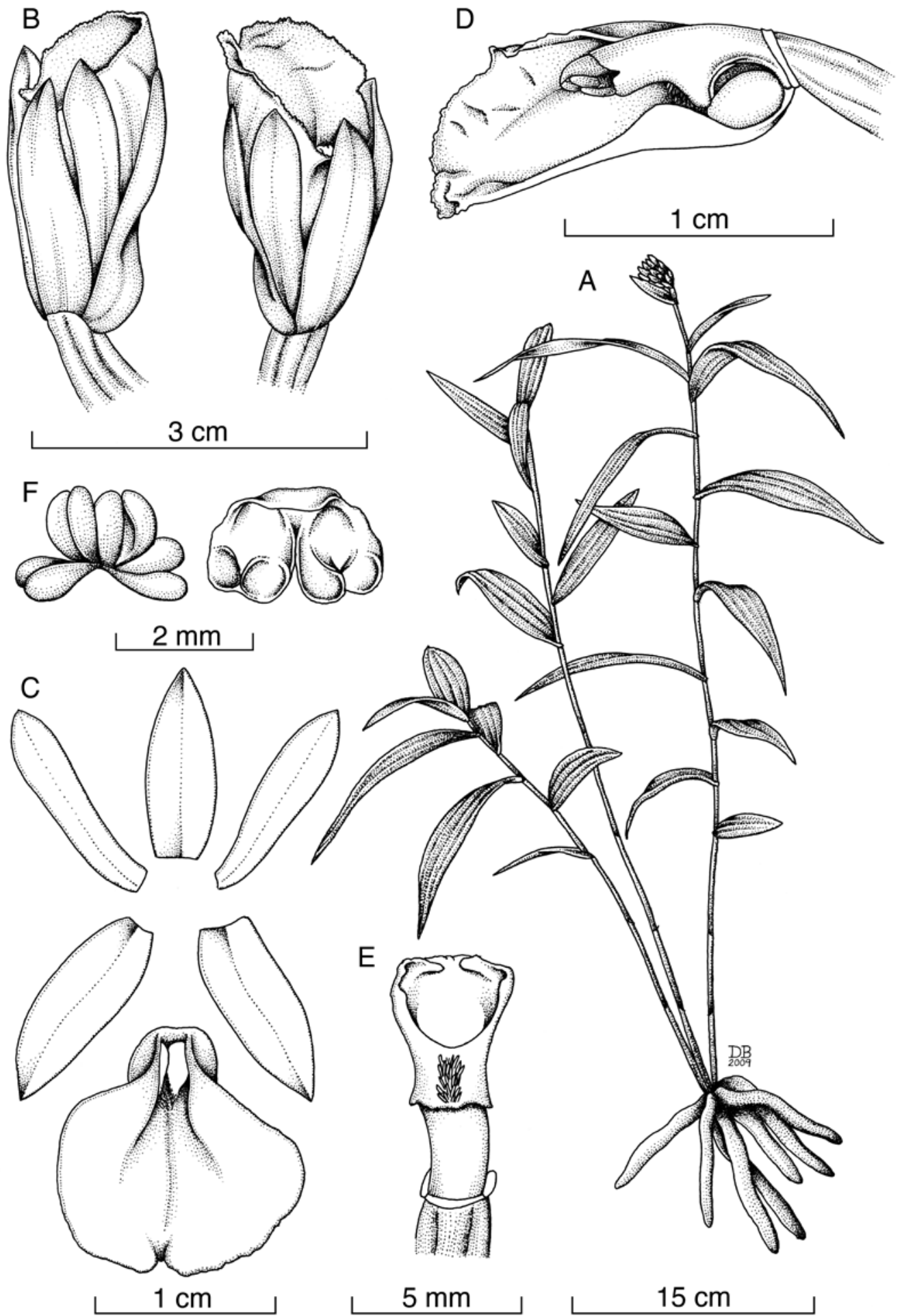

E

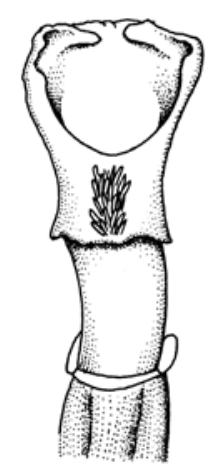

$5 \mathrm{~mm}$

$15 \mathrm{~cm}$

Figure 1. Elleanthus carinatus Dressler \& Bogarín. A - Habit. B - Flowers. C - Dissected perianth. D - Column and lip, lateral view. E - Column, frontal view. F - Pollinarium and anther cap. Drawing by D. Bogarín from the holotype. 


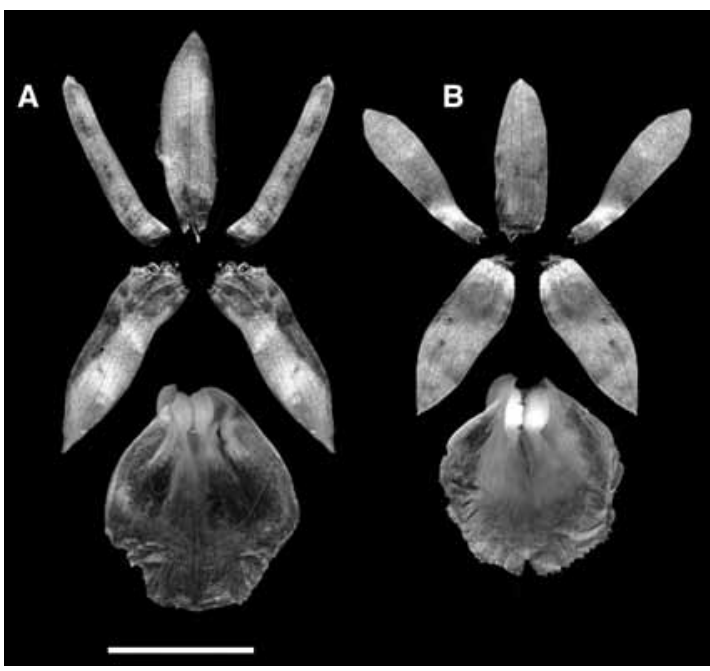

Figure 2. Comparison of the dissected perianth of: A Elleanthus cynarocephalus (Dressler 6697). B - E. carinatus (Dressler 7069). Scale bar $=1 \mathrm{~cm}$.

Until recently, we believed that there was only one member of Section Cephalelyna in Central America, but one of the "Sobralias" collected near Esperanza, in Cartago Province, developed a clearly capitate inflorescence, suggestive of Section Cephalelyna. As the inflorescence developed, it was clearly not the same as that of E. cf. cynarocephalus ${ }^{1}$ that grew near it in the greenhouse. In both plants, the basal bracts of the inflorescence were green, but in E.cf. cynarocephalus the upper bracts are rose-purple. In our plant from near Esperanza, the upper bracts may best be described as "pinkish café con leche." Further, the upper bracts are clearly carinate, with each keel ending in an apicule or a mucro. The upper bracts of the E. cynarocephalus are without keels, apicule or mucro. The flowers of these two plants are also distinct. In E. cynarocephalus the petals are linear or ligulate, as indicated by Garay ("linear-oblong") for this species (Fig. 2). In E. carinatus, the base of the column (basal to the mentum) is much shorter than the rest of the column, while these are subequal in E. cynarocephalus; also, the mentum is larger in

${ }^{1}$ We have not seen authentic E. cynarocephalus from northern Central America or Mexico. For now, we treat our one species with rose-purple bracts as E. cf. cynarocephalus, though it may actually be referable to an unnamed species, or a South American species.

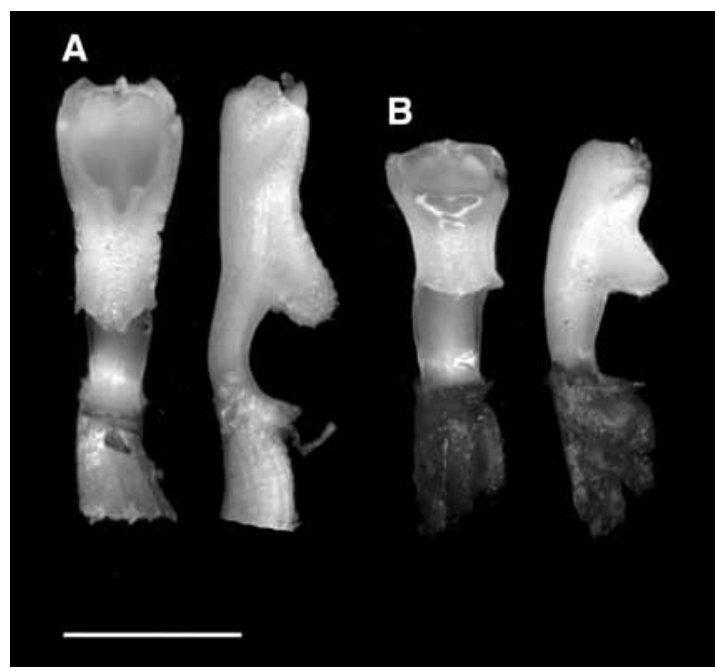

Figure 3. Comparison of the column of: A - Elleanthus cynarocephalus (Dressler 6697). B - E. carinatus (Dressler 7069). Scale bar $=5 \mathrm{~mm}$.

E. carinatus than in E. cynarocephalus (Fig. 3). A striking difference in the available material is that the flowers of E. carinatus open from the base of the head upwards (Fig. 8A), while those of E. cynarocephalus open from the apex downward.

Distribution: only known from Costa Rica.

Eтymology: from the Latin carinatus, keeled, referring to the marked keels on the bracts of the inflorescence.

Sobralia fragilis Dressler \& Bogarín, sp. nov.

TYPE: Costa Rica. San José: Dota, Falda este del Cerro Nara, 740-840 m, F. Pupulin 1099, D. Castelfranco \& L. Spadari, 14 Jan. 1999, flowered in cult., 11 August 2009, R.L. Dressler 7170 (holotype: CR; isotype: JBLspirit). Fig. 4, 8B.

Species numerosis (circa 22) carinis farinosis labelli a congeneribus diversa.

Roots 3-6 mm in diameter. Stems $75-100 \mathrm{~cm}, 4-5$ $\mathrm{mm}$ in diameter basally, 3.5-4 $\mathrm{mm}$ distally, dark purplish green mottled with pale green spots, young sheaths similar; leaves broadly elliptic, acute to acuminate, with 7 prominent veins beneath, 15-26.5 $x$ 4-8.6 cm. Inflorescence ellipsoid, 3.5-5 x 0.8-1.2 $\mathrm{cm}$, with 2-3 subtending foliar bracts $6-13 \times 1.8$ $5.2 \mathrm{~cm}$. Ovary sessile, 1.1-2.2 cm. Sepals greenish 

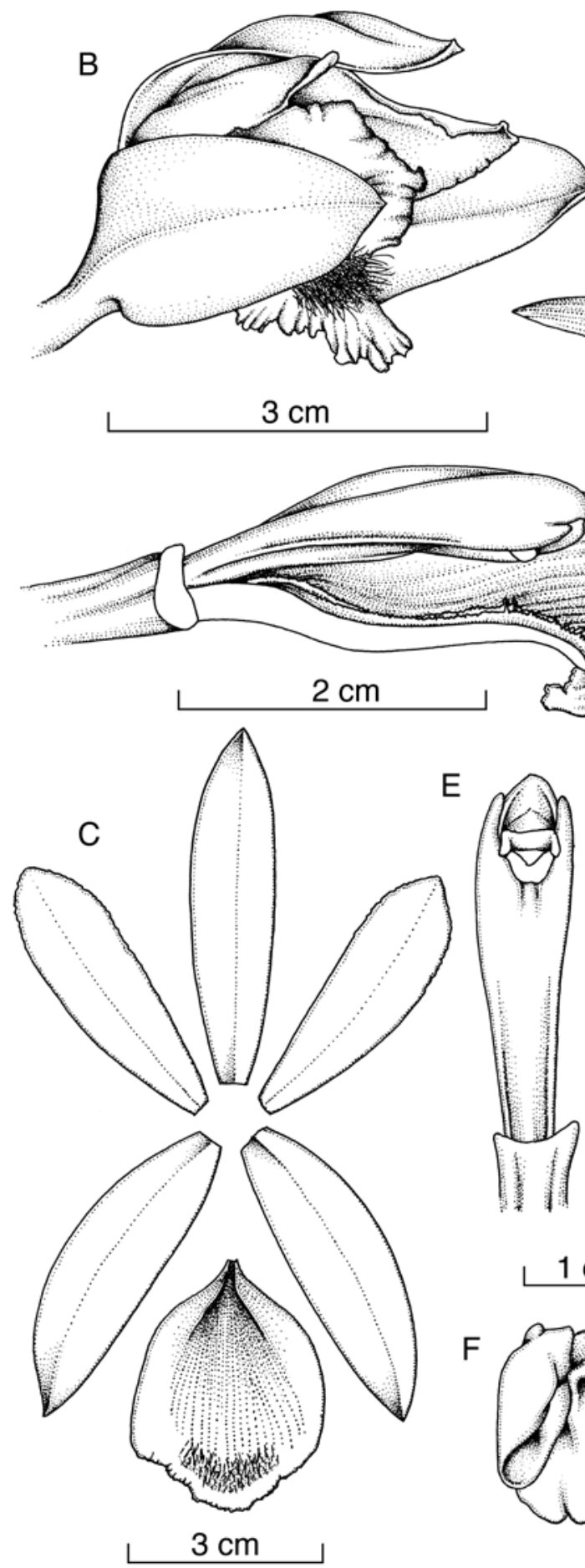

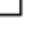

D
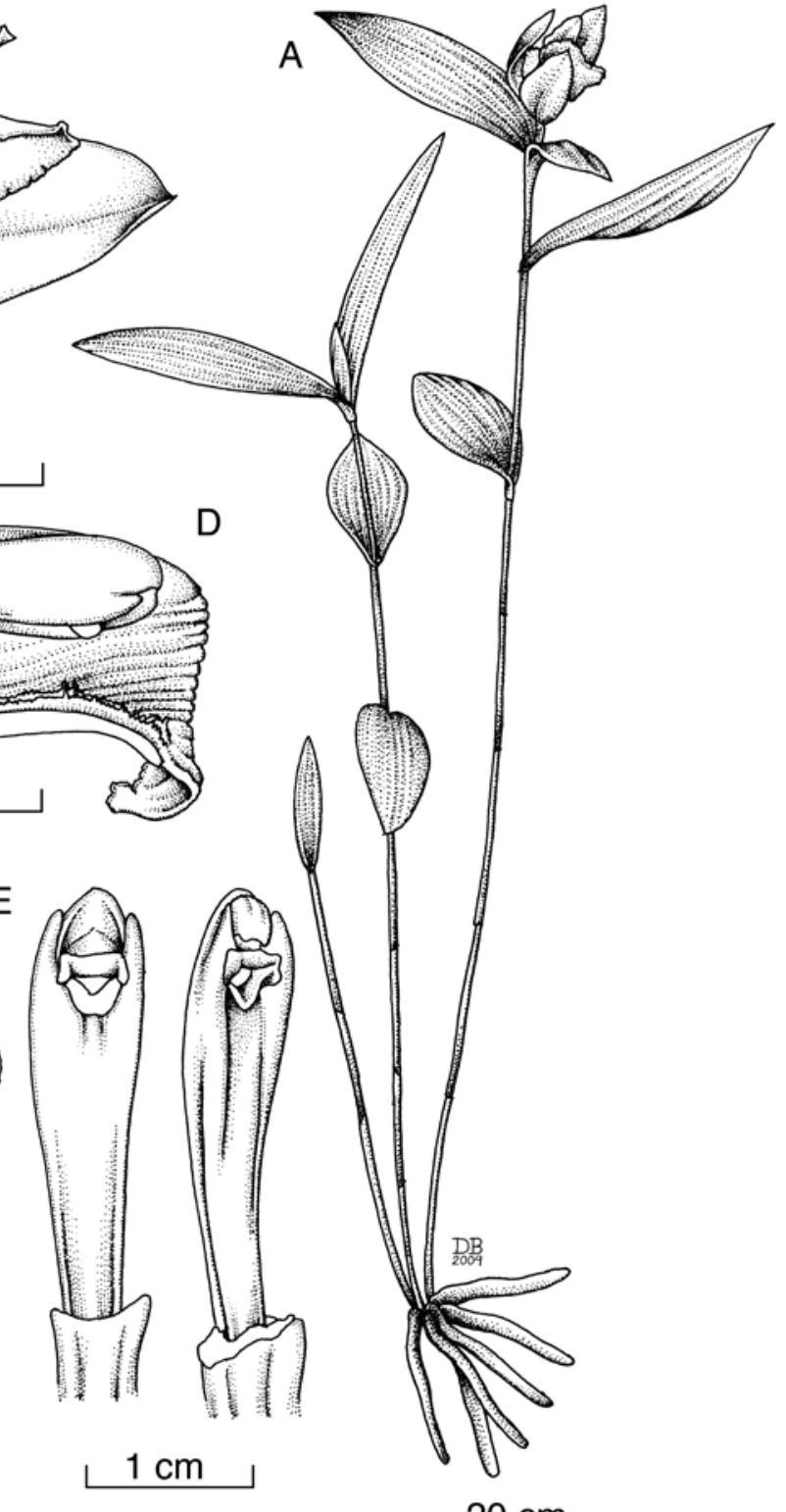

$\mathrm{F}$

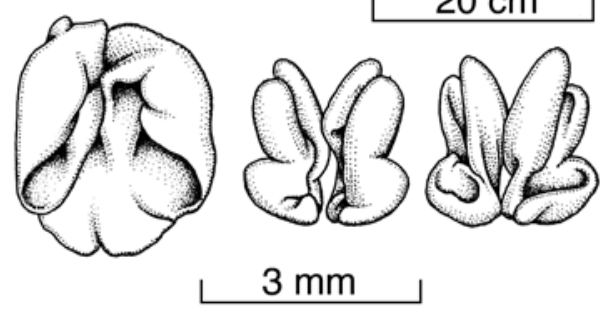

Figure 4. Sobralia fragilis Dressler \& Bogarín. A - Habit. B - Flower. C - Dissected perianth. D - Column and lip, lateral view. E - Column, frontal and side view. F - Pollinarium and anther cap. Drawing by D. Bogarín from the holotype. 
white without, with green apices. Petals white or cream with a green median vein without; midlobe of lip yellow. Lip with a purplish submarginal band on each side; base of lip minutely striped with white and brown within; sepaline tube 4-8 $\mathrm{mm}$. Dorsal sepal elliptic-oblong to oblanceolate, obtuse, apiculate, 3.5-5 x 1.1-1.5 cm. Lateral sepals ovatelanceolate or oblanceolate, obtuse, apiculate. Petals narrowly obovate or oblong-elliptic, obtuse, 2.8-4.7 x 1-1.5 cm. Lip subquadrate-subobovate, 3.2-4 x 3-3.8 cm, basal calli 7-9 mm; base of lip with ca. 23 low ridges, these becoming higher and more ornate distally. Column $20-27 \mathrm{~cm} \times$ 4.5-6 mm laterally, $5-5.5 \mathrm{~cm}$. dorsoventrally, lateral arms 1-2 mm.

This species is one of the most distinctive known to us. It does not resemble any other species known from Central America. It is, in fact, one of the most difficult to deal with. The base of the lip has about 22 low keels. The keels and the alternating grooves appear as narrow stripes. The keels become much higher in the distal portion of the lip, but they are actually soft and mealy. It is difficult to handle the lip without rubbing off the "keels." All Sobralia flowers are delicate, but it is almost impossible to handle the lips of this species without destroying the surface. Thus, we have chosen the epithet "fragilis" for this species. It is quite possible that this species is related to a Colombian species that has been called "S. suaveolens." The so-called "S. suaveolens" has prominent "crests" on the lip that are actually a powdery, yellow substance, and may act as pseudopollen to attract female bees that gather the pseudopollen as food for their brood. This Colombian species has the lip very much more deeply divided than either Sobralia fragilis or the true $S$. suaveolens. It is quite possible that $S$. fragilis and the misidentified Colombian species are related to each other and they may both attract pollinators by pseudopollen.

We have only two plants of $S$. fragilis, but the species clearly show synchronized flowering, with both plants usually flowering on the same days.

\section{Distribution: only known from Costa Rica.}

Eтymology: from the Latin fragilis, "fragile", referring to the delicate, easily damaged surface of the lip.

\section{Sobralia geminata Dressler \& Bogarín, sp. nov.}

TYPE: Costa Rica. Cartago: Paraíso, Cachí, Peñas Blancas, camino a Cerros Duán, 949'51.3”N 8346'13.1”'W, $1400 \mathrm{~m}$, bosque muy húmedo premontano, terrestre cerca del camino, flowered in cult. 1 october 2009, R.L. Dressler 7173 (holotype: CR; isotype: JBL-spirit). FIG. 5, 6, 8C.

A Sobralia chrysostoma Dressler similis, floribus minoribus, labello maculis brunneis plerumque aliquantum albo notato recedit.

Roots 5-7 $\mathrm{mm}$ in diameter; stems $20-140 \mathrm{~cm}$, basally $5-6 \mathrm{~mm}$ in diameter, distally $3.5-5 \mathrm{~mm}$ in diameter. Stems dark greenish purple mottled with pale green, young sheaths similar, especially opposite the next leaf blade. Leaves elliptic or broadly elliptic, acuminate, apiculate, 11-25 x 4-7.4 $\mathrm{cm}$, with 7-9 raised veins beneath. Inflorescence ellipsoid, 3.5-4 x 0.7-1 cm; smaller foliar bracts $3-10 \times 1.5-5 \mathrm{~cm}$; ovary $10-22 \mathrm{~mm}$, sepaline tube $1-2$ $\mathrm{cm}$. Sepals greenish cream with green mid-veins, apically green. Petals white without, lip yellow with white margins and usually some white on disk, disk with pale brown spots or streaks. Dorsal sepal oblong-elliptic or oblanceolate-elliptic, apiculate, 4.2-6.6 x 1.25-1.8 cm. Lateral sepals oblongelliptic or narrowly obovate, acute, 4.5-6 x 1.5-2.3 $\mathrm{cm}$. Petals oblong-elliptic or narrowly obovate, subobtuse to subacute; $4.3-7.1 \times 1.6-2.5 \mathrm{~cm}$. Lip obovate, $5.3-6.5 \times 4.2-4.8 \mathrm{~cm}$, basal calli $0.8-1.8 \mathrm{~cm}$, median keels 4-9, low, sometimes with 1-2 shallow grooves, midlobe crisped. Column 2.8-4 cm x 5-9 $\mathrm{mm}$ laterally $\times$ 5-8 $\mathrm{mm}$ dorsoventrally; lateral lobes (arms) small, tooth-like, 1.5-1.6 mm.

Paratypes: Costa Rica. Alajuela: San Ramón, Piedades, Piedades Norte, road to Bajo La Paz, ca. $\mathrm{km} \mathrm{3,} \mathrm{along} \mathrm{the} \mathrm{Río} \mathrm{San} \mathrm{Pedro,} 10^{\circ} 08^{\prime} 58.7^{\prime} \mathrm{N}$ $84^{\circ} 34^{\prime} 03.3^{\prime \prime} \mathrm{W}, 1300 \mathrm{~m}$, premontane wet forest, secondary and remnants of primary vegetation, R.L. Dressler 7011, A. Karremans \& F. Pupulin, 19 February 2008, flowered and pressed in cult. in Lankester Botanical Garden, July 2009, R.L. Dressler 7172 (CR). Cartago: Jiménez, Pejibaye, Alto del Humo, 23 May 2005, R.L. Dressler 6561, flowered and pressed in cult. in Lankester Botanical Garden, 14 August 2007, R.L. Dressler 6947 (CR). Paraíso, Orosi, 

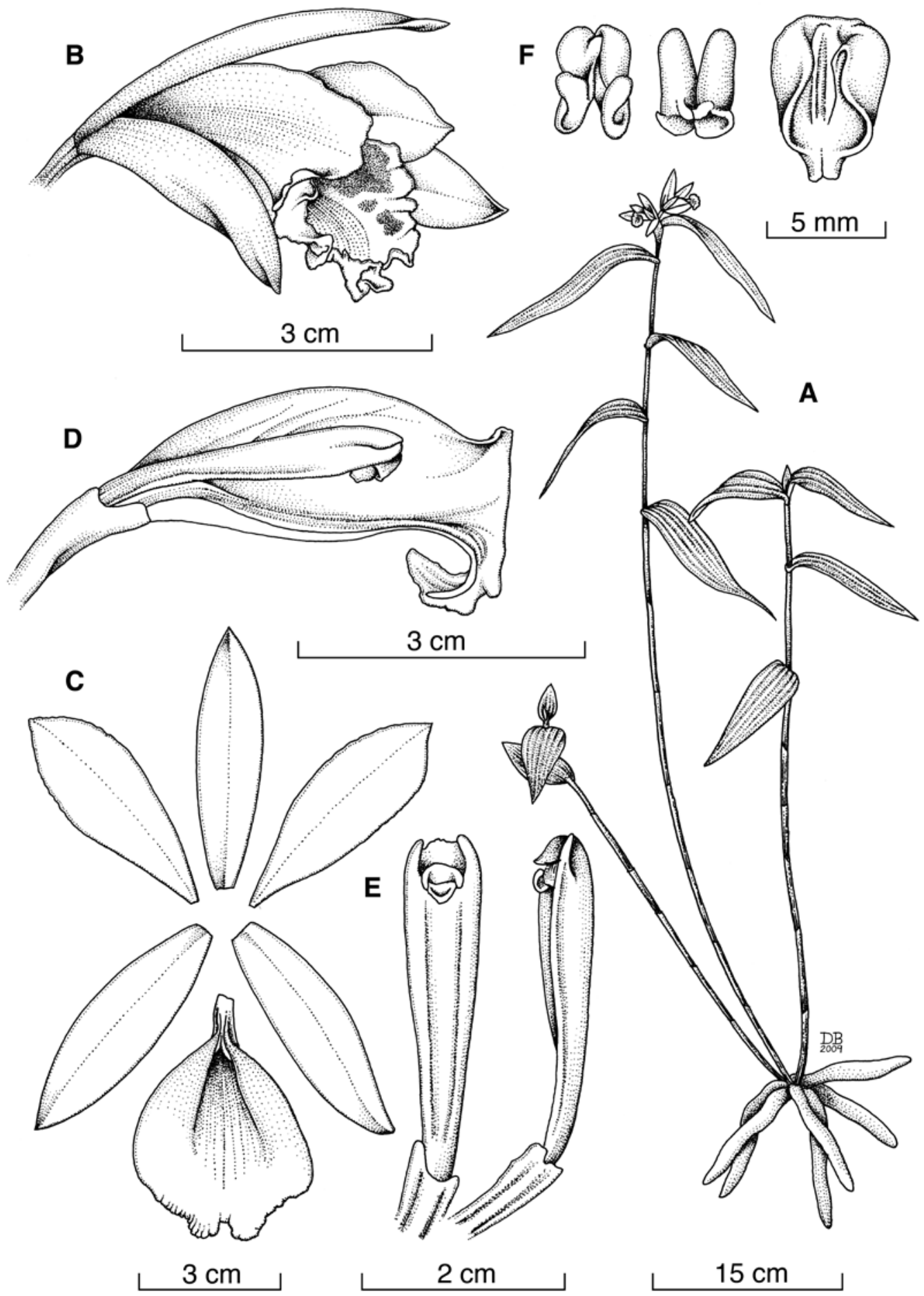

Figure 5. Sobralia geminata Dressler \& Bogarín. A - Habit. B - Flower. C — Dissected perianth. D — Column and lip, lateral view. E - Column, frontal and side view. F - Pollinarium and anther cap. Drawing by D. Bogarín from the holotype. 
Tapantí, road between Tapantí and Tausito, ca. $500 \mathrm{~m}$ before Tejos restaurant, $9^{\circ} 46^{\prime} 16.5^{\prime \prime} \mathrm{N} 83^{\circ} 47^{\prime} 24.6$ "W, $1453 \mathrm{~m}$, premontane wet forest, $R$. Dressler 6661, M.A. Blanco \& D. Bogarin, 23 December 2005, flowered and pressed in cult. in Lankester Botanical Garden, 6 July 2006, R.L. Dressler 6788 (CR). Turrialba, La Suiza, road between Pacayitas and La Suiza, $2 \mathrm{~km}$ south of Pacayitas, 9०52'29.9”N $83^{\circ} 35^{\prime}$ 03.6.4”W, $1150 \mathrm{~m}$, premontane wet forest, 8 March 2006, R.L. Dressler 6673, D. Bogarín, A. Karremans \& F. Pupulin, flowered and pressed in cult. in Lankester Botanical Garden, 10 July 2006, R.L. Dressler 6789 (CR).

\section{Distribution: only known from Costa Rica.}

Etymology: from the Latin geminatus, "twinned," referring to the usually paired flowers.

We first found small plants of this species in 2005. When they flowered, the flowers reminded us of $S$. chrysostoma, but we found the flowers to be consistently different from those of $S$. chrysostoma, so we thought it to be an unnamed species. In May of 2007 one of us (RLD) travelled to the northeast of Cartago Province, hoping to find a new species once found near Bonilla Arriba. There were colonies of a Sobralia along the roadsides and most of the youngest mature stems each had 2 capsules. My first thought was "The pollinators must be very efficient here," but it was later clear that this population (PacayasSanta Cruz), at least, is self-pollinating. This was confirmed when other plants in the Lankester Botanical Garden often set fruits without pollination. Most of the plants produce only two flowers on each stem (either simultaneously or serially), so we have called it Sobralia "geminata," because of the "twin" flowers. As one might expect from a partially self-pollinating species, there is local variation. Obviously, where the flowers are consistently selfed, bees do not carry mutant genes from one colony to another. In San Ramon, we found an attractive form that had the median groove on the lip a bit wider and sometimes had a slender, jointed, column appendage (in Sobralia, this appendage is more an "arm," than a "wing"). This was so different from anything else we had seen in Sobralia that we thought it to be a new species. However, when the same plants flowered again, they usually lacked the unique appendage, and they were self-pollinating.

The flowers of Sobralia geminata resemble those of $S$. chrysostoma, but they are consistently smaller, and they also have brownish spots or streaks on the lip, and some white near the apex. Sobralia chrysostoma frequently has dark purplish spots on the stems and sheaths, while the stems of $S$. geminata are consistently more heavily spotted than any other species in our area. The form of the stigma is quite variable in this species. The stigma varies a good deal in size, often being cuplike, as in most other species, or it may be straight, tongue-like, and subparallel with the column axis. In this latter pattern, the pollen probably germinates on the upper side of the stigma, thus accomplishing selfpollination.

Most Sobralia species are markedly syncronized (or "gregarious") in their flowering, often flowering on the same day over a large area. One would not really expect a self-pollinating population to follow strict synchrony, yet the plants of this species in Lankester Botanical Garden usually flower on the same days. The plants collected south of Cartago have consistently flowered on the same days, even though they are quite self-pollinating. One doubts that there is much selective pressure for synchrony in self-pollinating plants, but, at the same time, there is probably little selective pressure against synchrony in such populations.

Our first impression of S. geminata was that it was predominantly self-pollinating. We have seen some selfing in most of the plants we have cultivated, as this description was in preparation, we had a number of plants flowering on 31 August 2009 and again on 9 September. Of the 16 flowers produced on 31 August, there were 6 capsules; while on 9 September there were 24 flowers, of which 15 remained as capsules. It is clear that the populations of Pacaya - Santa Cruz and Cartago - Cangreja are largely self-pollinating. One of the large plants from Cartago - Cangreja, however, had flowered heavily about 6 months earlier, and 3 capsules were allowed to remain on the plant. This plant has not produced any flowers in the recent flowerings. The two large plants from Cachí have flowered along with the rest of the $S$. geminata, but no capsules developed on either of these plants. Similarly, Ademar Silveira reports $S$. geminata in the buffer zone northeast of the 


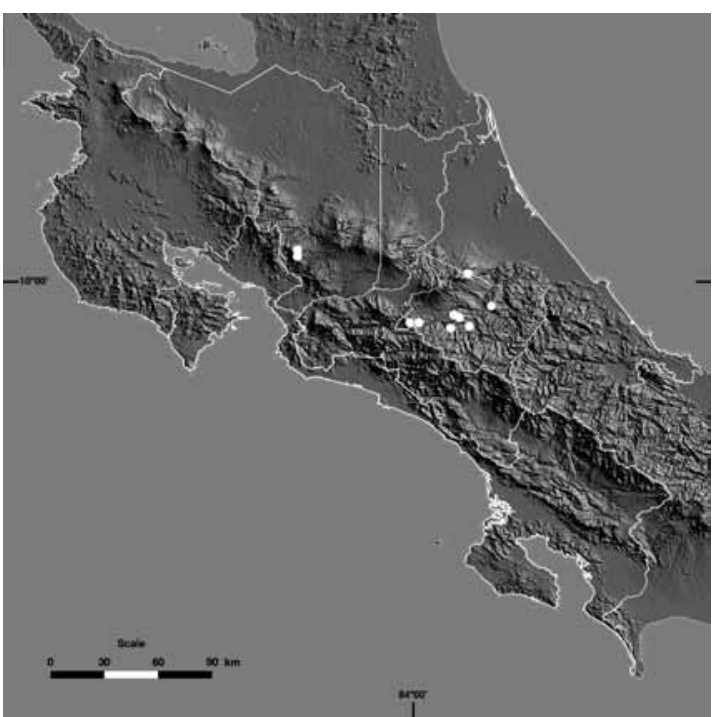

FIgURE 6. Distribution map of Sobralia geminata in Costa Rica.

Tapantí Refuge, but has observed no self-pollinating in the species in that area.

Now that we know $S$. geminata, we find plants of this species nearly everywhere we go in central Costa Rica. Indeed, we are rather tired of seeing them.

\section{Sobralia sotoana Dressler \& Bogarín, sp. nov.}

Type: Panama. Veraguas, collected near road north of Santa Fé de Veraguas, flowered in culture in Jardín Botánico Lankester, pressed from cultivation, 8 August 2009, R.L. Dressler 7168 (holotype: CR; isotype: JBLspirit). FIG. 7, 8D.

Species Sobralia aspera Dressler \& Pupulin similis, labello interius intense aurantiaco, callis basalibus farinosis differt.

Roots to $5 \mathrm{~cm}$ in diameter. Stems $33-75 \mathrm{~cm}$, ca. $3 \mathrm{~mm}$ in diameter basally, $2 \mathrm{~mm}$ distally, sheaths slightly scurfy. Leaves elliptic or lance-elliptic, long acuminate, $15.0-23.5 \times 2.2-5 \mathrm{~cm}$. Inflorescence $3-5.0 \times 0.5 \mathrm{~cm}$, outer bract acuminate, inflorescence usually horizontal or nodding; subtending foliar bracts acuminate, $15-16$ x 1.4-1.7 cm. Ovary sessile, 13-17 $\mathrm{mm}$. Sepaline tube 12-15 mm. Dorsal sepal 3.3-4.5 x 1-1.6 cm, elliptic or lanceolate, subobtuse. Lateral sepals elliptic-lanecolate, tapering, 3.2-4.5 x 1.1-1.5 $\mathrm{cm}$. Petals obovate, subobtuse, $3.1-3.5 \times 1.2-1.3 \mathrm{~cm}$.
Lip oblong-obovate, 4-4.2x 2.8-3.1 cm, without keels; basal calli $c a .6 \mathrm{~mm}$; column clavate, markedly thicker below stigma, $23-24 \mathrm{~cm} \times 0.5 \mathrm{~mm}$ laterally $\times 4-4.5 \mathrm{~mm}$ dorsoventrally.

Distribution: only known from Panama.

Eponymy: In honor of Miguel Angel Soto Arenas, to whom this issue of Lankesteriana is dedicated.

When we visited Finca Dracula (Cerro Punta, Panama) in 2006, there were two relatively small Sobralias flowering. The staff at Finca Dracula referred to one as "Veraguas" and the other "Santa Fe," but the city of Santa Fe is in Veraguas province, so these terms seemed a bit unclear. Erick Olmos explained that both species were found in the same area, near a lake north of Santa Fe, on the road that may eventually reach Calovébora, on the Caribbean coast. In any case, "Veraguas" proved to be indistinguishable from Sobralia aspera, earlier described from Costa Rica (Dressler \& Pupulin 2008), while the other is clearly a distinct species. Further, the Costa Rican and the Panamanian plants of $S$. aspera flower on the same days, thus supporting their specific identity. Both of these resemble Sobralia leucoxantha, S. macra, S. kruskayae and S. tricolor, while Sobralia "Santa Fe" is clearly distinct from the other species just mentioned. The plant had produced very few flowers in the first year in Costa Rica, but in 2009 it has been quite floriferous.

Sobralia sotoana resembles $S$. aspera vegetatively, though the plant is a bit smaller. The upper stems are weakly but distinctly zig-zag, and the inflorescences much more markedly nodding, or reflexed, so the flowers are somewhat pendant. The flowers are a bit smaller and the lips are intense orange within with a narrow white margin.

ACKNOWLEDGEMENTS. We acknowledge the scientific services of the Costa Rican Ministry of Environment, Energy and Telecommunications (MINAET) and its National System of Conservation Areas (SINAC) together with Autoridad Nacional del Ambiente (ANAM) of Panama, for issuing the collecting permits under which wild species treated in this paper were collected, and for extending the necessary documentation to import orchid specimens from abroad for comparison. We are indebted to Andrés 


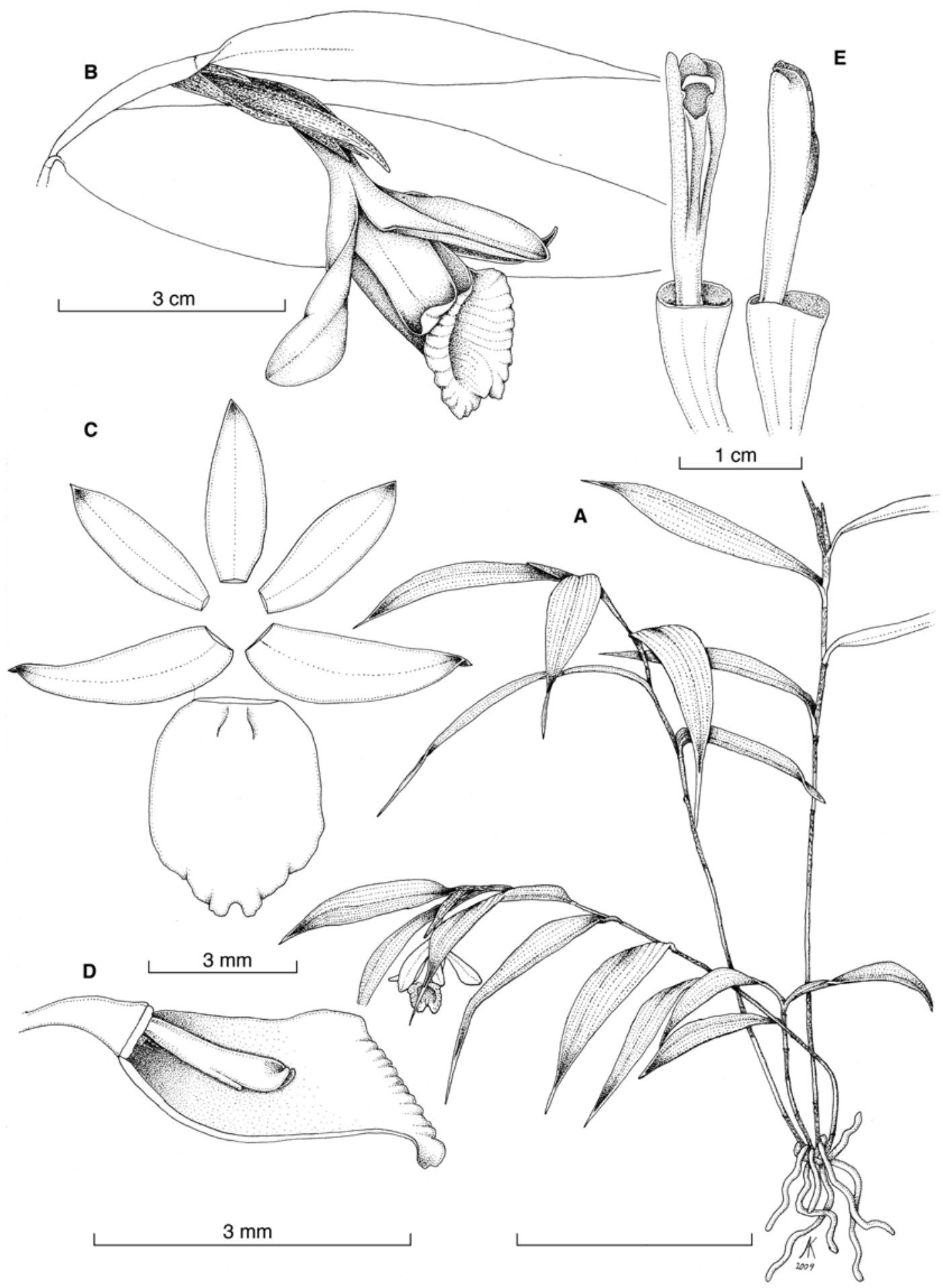

Figure 7. Sobralia sotoana Dressler \& Bogarín. A - Habit. B — Flower. C - Dissected perianth. D - Column and lip, side view. E - Column, frontal and side views. Drawing by A. Karremans from the holotype. 

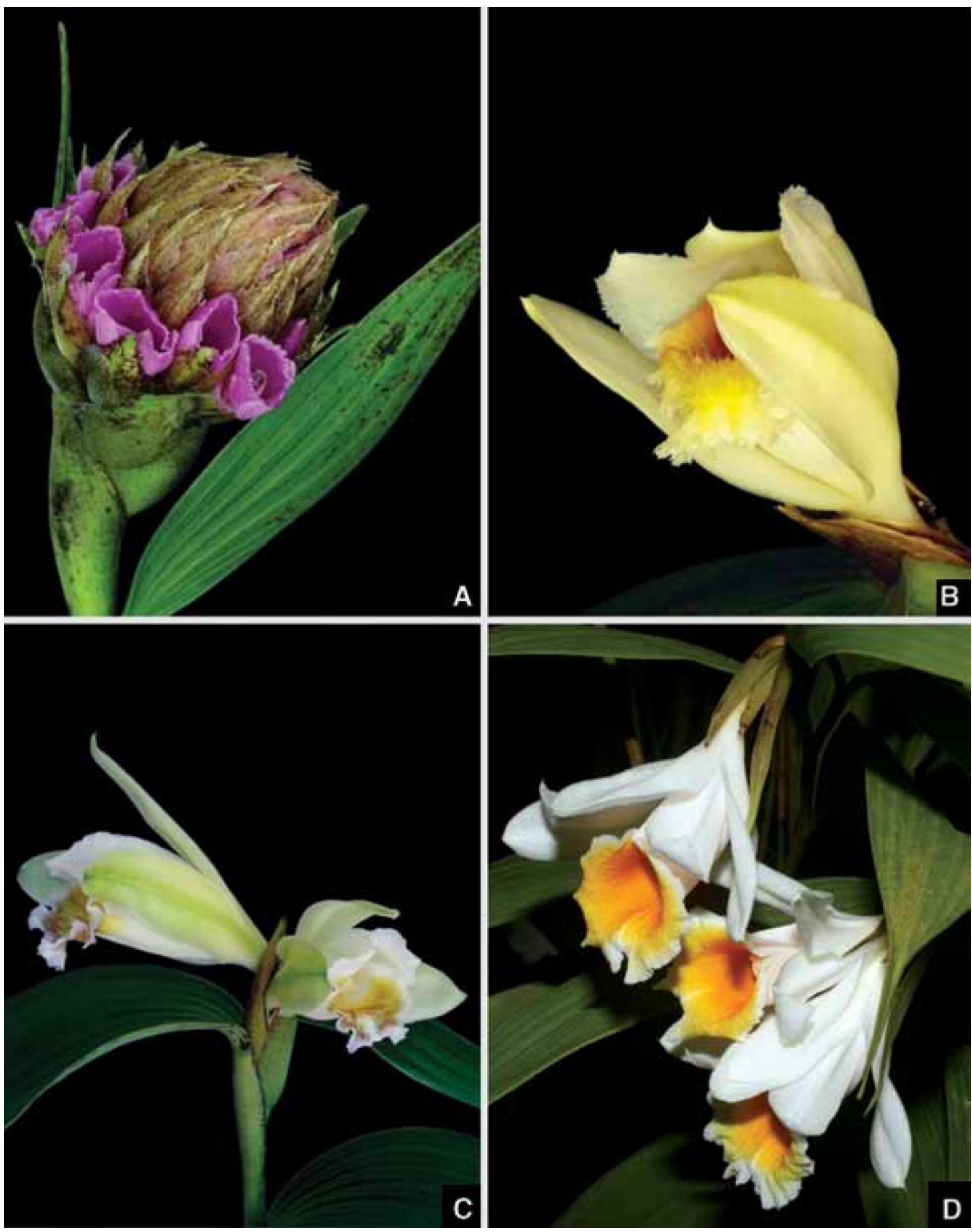

FIGURE 8. Flower morphology of: A - Elleanthus carinatus. B - Sobralia fragilis. C - Sobralia geminata. D -

Sobralia sotoana. All pictures taken from the clonotypes. A - C by D. Bogarín, D by K. Dressler. 
Maduro and Erick Olmos of Finca Dracula, Panama, who provided critical material and information to describe this species. Adam Karremans kindly prepared the drawing of S. sotoana. This article is part of Project 814-A7-196, "Systematic studies of Sobralia," supported by the VicePresidency of Research, University of Costa Rica.

\section{Literature Cited}

Dressler, R.L. \& F. Pupulin. 2008. La identidad de Sobralia leucoxantha con tres especies nuevas, dos muy afines y una más lejana. Orquideología 25(2): 134-151.

Garay, L. A. 1978. Studies in American Orchids X. Bot. Mus. Leafl. 26(1): $1-38$. 
LANKESTERIANA 